\title{
Activation of B cells using Schneider 2 cells expressing CD40 ligand for the enhancement of antigen presentation in vitro
}

\author{
Sung Hee Yoon ${ }^{1}$, Hyun II Cho' \\ and Tai Gyu Kim ${ }^{1,2}$ \\ ${ }^{1}$ Department of Microbiology \\ College of Medicine \\ The Catholic University of Korea \\ Seoul 137-701, Korea \\ ${ }^{2}$ Corresponding author: Tel, 82-2-590-1216; \\ Fax, 82-2-3476-7355; E-mail, kimtg@catholic.ac.kr
}

\section{Accepted 21 October 2005}

Abbreviations: CD40L, CD40 ligand; DC, dendritic cells; ELISPOT, enzyme-linked immunospot; LCL, lymphoblastoid B cell line; MLR, mixed lymphocyte reaction; PBL, peripheral blood lymphocytes; S2, Schneider 2

\footnotetext{
Abstract

CD40 ligand (CD40L) expressed by activated CD4 ${ }^{+} \mathrm{T}$ cells is a family member of membrane bound TNF family ligand and its interaction with CD40 expressed in APC has been shown to contribute in enhancing immune response. Exogenous stimulation through CD40 has been performed using soluble trimeric CD40L, anti-CD40 monoclonal antibody and cells expressing CD40L. Schneider 2 (S2) cells, a cell line derived from Drosophila melanogaster, was transfected with a plasmid vector, pAc5.1/V5-HisA, for the constitutive expression of CD40L (S2-CD40L). Upon incubation of S2-CD40L with B-lymphocytes for 6 days, activated $B$ cells were examined by counting $B$ cell numbers and for activation markers including CD86 and HLA Class II molecules. The activated B cells were tested for its efficient APC function by mixed lymphocyte reactions (MLR) and enzymelinked Immunospot (ELISPOT) assay. S2-CD40L was cultured for a year and maintained CD40L expression (>90\%). S2-CD40L induced B cell activation as demonstrated by increment of total B cells and up-regulation of CD86 and MHC Class II molecules. Activated $B$ cells pulsed with peptide from human cytomegalovirus pp65 antigen efficiently induced both proliferation and IFN- $\gamma$ secretion of T cells. Our result suggests that S2-CD40L can efficiently and conveniently generate B cells as a functional APC and represents a potential role for B-cell mediated
}

\author{
cancer immunotherapy.
}

Keywords: antigen-presenting cells; antigens; B-lymphocytes; CD40; CD40 ligand; immunotherapy

\section{Introduction}

Cancer immunotherapy has been associated with augmentation of immune response via in vivo vaccination or ex vivo expansion of antigen specific effector cells that show cytotoxicity and secretion of inflammatory molecules. Preclinical studies have demonstrated the important role of APC in antigen presentation to prime $\mathrm{T}$ lymphocytes. For effective induction of $\mathrm{T}$ cell mediated immune response, efficient presentation of antigen peptides is required. Among the various APCs including dendritic cells (DC) (Metlay et al., 1989; Romani et al., 1989; Inaba et al., 1990; Steinman et al., 1993; Salusto et al., 1994; Celluzzi et al., 1996; Paglia et al., 1996), activated macrophages (Rock et al., 1993) or activated B cells (Gollob et al., 1993; Liu et al., 1994; 1995; Topalian et al., 1994; Constant et al., 1995; Mitchell et al., 1995; Schultze et al., 1995; Ke et al., 1996; Vidard et al., 1996), lymphoblastoid B cell lines (LCL) (Livingston et al., 1997; Barbara et al., 2002), the best known APC is DC for its potency in antigen capture, processing and migration (Steinman et al., 1993).

Most of studies on generation of antigen specific $T$ cells in vitro have used dendritic cells for its capacity; antigen capture and efficient presentation. Antigenloaded DC has been clinically tested in phase II and III trials for the treatment of cancer including melanoma, prostate cancer, B cell lymphoma, cutaneous T cell lymphoma and metastatic renal cell carcinoma (Hsu et al., 1998; Thurner et al., 1999; Kugler et al., 2000; Banchereau et al., 2001; Heiser et al., 2002; Rini et al., 2002; Meier et al., 2003). However, in order to prime naive $\mathrm{T}$ cells to be antigen specific, the fact that DCs only constitute $0.1-0.5 \%$ of human PBMC has hampered generating a large numbers of matured DC (Girolomoni et al., 1997). To overcome the small portion of DCs in PBMC, monocytederived DCs have been most widely used as they can be simply generated using plastic adherent method with GM-CSF and IL-4 (Bender et al., 1996). DCs generated via this method are not fully functional in stimulating antigen-specific T cells in vitro or 
migrating into the regional lymph nodes in vivo. Various stimuli such as inflammatory cytokines are required for complete maturation of immature DCs. Recently, cellular immunotherapy for clinical application requires more number of alternative APCs as potent as DCs that can be generated in a short time and can be expanded continuously.

CD40L, mainly expressed on activated $\mathrm{CD}^{+} \mathrm{T}$ lymphocytes, has been one of the most commonly used inducing molecule of B cell activation. It causes upregulation of activation signal to $B$ cells, costimulatory molecules such as CD80, CD83, CD86 and MHC Class I and II at level comparable to DCs (joachim et al., 1997). Studies on B cell activation via CD40-CD40L interaction have been performed with various types of CD40L including soluble form (sCD40L), monoclonal antibody or cellular mediated expression. In any cases, CD40-CD40 ligand interaction caused $B$ cell proliferation. The activated $B$ cells demonstrated its capacity as functional APC by generating Ag-specific cytotoxic $\mathrm{T}$ lymphocytes (CTL) in vitro (Eisei et al., 2002; Michael et al., 2002).

In the current study, we developed non-allogenic and non-xenogenic $B$ cell stimulating system by establishing a cell line derived from Drosophila melanogaster, Schneider 2 (S2) cells stably expressing CD40 ligand (S2-CD40L). Here we observed that the use of S2-CD40L allows rapid activation of B cells and CD40-activated B cells fulfill the criteria of optimal APC.

\section{Materials and Methods}

\section{Donors and cell lines}

Leukocytes obtained from healthy donors, HLA$\mathrm{A}^{*} 0224^{+}$and $\mathrm{HLA}-\mathrm{A}^{*} 0201^{+}$by leukapheresis were separated by density centrifugation through Ficoll (Pharmacia, Piscataway, NJ) to yield PBMC. Isolated peripheral blood monocytes were then washed with PBS, resuspended in Iscove's modified Dulbecco's medium (IMDM) (Cambrex, Walkersville, MD) medium containing 10\% FBS (Cambrex).

\section{Constructs}

Reverse-transcribed cDNA for human CD40 ligand isolated from activated $\mathrm{CD}^{+} \mathrm{T}$ cells served as a template for the PCR amplification. The forward primer leaves EcoRI at the 5' end and Notl at the 3' end. Conditions for PCR were as follows: $5 \mathrm{~min}$ at $95^{\circ} \mathrm{C}$, followed by 35 cycles, each consisting of $30 \mathrm{~s}$ at $95^{\circ} \mathrm{C}, 30 \mathrm{~s}$ at $57^{\circ} \mathrm{C}$, and $1 \mathrm{~min}$ at $72^{\circ} \mathrm{C}$, followed by a final extension of unfinished products for $10 \mathrm{~min}$ at $72^{\circ} \mathrm{C}$. The PCR product for human CD40L was di- gested with EcoRI and Notl and inserted into the S2 cell expression vector, pAc5.1/ V5-HisA.

\section{Generation of S2 expressing CD40 ligand}

The $20 \mu \mathrm{g}$ of plasmid pAc5.1/V5-HisA-hCD40L and $1 \mu \mathrm{g}$ of selection vector $\mathrm{pCOHYGRO}$ are transfected into a cell line derived from Drosophila melanogaster, S2 cells (Invitrogen, Carlsbad, CA) by calcium phosphate method. For stable transfectants, cells are suspended and cultured in complete DES expression medium (10\% FBS) (Cambrex) containing $300 \mu \mathrm{g} / \mathrm{ml}$ hygromycin-b. The resistant cells are tested for expression by flow cytometry and the expression of the human CD40L on the transfectants has been stable over a period of $>1 \mathrm{yr}$. Phenotypic analysis has been performed regularly on these cells and in all analysis $>90 \%$ of S2-CD40L cells were positive for human CD40L.

\section{Activation of B cell}

$B$ cells were purified by means of the MiniMACS separation method (Miltenyi Biotech, Bergisch Gladbach, Germany) using cocktail of biotin-conjugated monoclonal antibodies against CD2, CD14, CD16, CD36, CD43 and CD235a (Glycophorin A). The fraction of $B$ cells in the starting sample was determined by flow cytometry $>90 \%$. The purified B cells were resuspended at a concentration of $5 \times 10^{5} / \mathrm{ml}$ in IMDM medium containing $10 \%$ FBS and were plated on 12-well plates. B cell suspension was cocultured with anti-CD40 mAb $(10 \mu \mathrm{g} / \mathrm{ml})$ or S2CD40L cells with at various ratio in the presence of 4 $\mathrm{ng} / \mathrm{ml}$ IL-4 (Endogen, Woburn, MA), $5 \mu \mathrm{g} / \mathrm{ml}$ insulin (Sigma), $50 \mu \mathrm{g} / \mathrm{ml}$ transferrin (Boehringer Mannheim, Indianapolis, IN) at $37^{\circ} \mathrm{C}$ in $5 \% \mathrm{CO}_{2}$. Cultured cells were transferred to new plates with fresh S2-CD40L cells or anti-CD40 mAb on day 3 . Before the addition of S2-CD40L, dead cells and debris were removed from Ficoll density centrifugation. At day 6, activated $B$ cells were Ficoll-density centrifuged followed by washing with PBS twice to remove nonviable cells including remaining S2-CD40L cells.

\section{Flow cytometry}

Phenotypes of CD40 activated B cell populations and CD40L on S2 cells were analyzed by flow cytometry using a FACScan flow microfluorometer (BD Biosciences, Mountain View, CA) as previously described (Kim et al., 2004). Fluorescence profiles were generated by analyzing 10,000 cells and displayed as histogram vs. cell numbers. Activated B cells were analyzed for PE-conjugated CD86 and FITC-conjugated HLA Class II and S2-CD40L for PE-conjugated CD154. Apoptic cells were analyzed 
for PE-conjugated AnnexinV. All fluorescence-conjugated Abs were purchased from BD Pharmingen. In brief, 1 million viable $B$ cells in $100 \mu$ of PBS were rinsed twice with PBS containing $2 \%$ FBS. The cells were then stained for $20 \mathrm{~min}$ with $0.5 \mu \mathrm{g}$ of the following appropriate mAbs. The stained cells were washed and fixed with $1 \%$ paraformaldehyde in PBS. FACS analysis was performed using the abovementioned FACScan flow cytometer and CellQuest software (BD Biosciences).

\section{Mixed lymphocyte reactions (MLR)}

MLR is performed for measuring viable T cell using XTT assay as previously described (Lee et al., 2005). Briefly, whole $\mathrm{CD} 3^{+} \mathrm{T}$ cells or $\mathrm{T}$ cell subsets from healthy individuals were plated at $1 \times 10^{5} \mathrm{~T}$ cells/well with $10^{5}$ irradiated (32 Gy) CD40 activated B cells or B cells/well in $100 \mu \mathrm{l}$ RPMI-1640 supplemented with 10\% FBS (Cambrex), 2 mM glutamine (Gibco/BRL, Gaithersburg, MD) in 96-well plates for up to 6 days. On day 6 , viable cells were labeled with $50 \mu \mathrm{l}$ of 2,3-bis[2-methoxy-4-nitro5-sulfophenyl]-2H-tetrazolium-5-carboxanilide inner salt (XTT) reagents (Cell Proliferation kit II) according to the manufacturer's protocol (Boehringer Mannheim) as a measure of cell proliferation. Absorbance was measured with a Thermo max microplate reader at $490 \mathrm{~nm}$ and reference wavelength of $650 \mathrm{~nm}$.

\section{Enzyme-linked immunospot (ELISPOT) assays}

ELISPOT assays were performed as described earlier (Kondo et al., 2002). In brief, a commercially available ELISPOT kit was used (AID, Jessup, MD). $B$ cells activated for 6 days by S2-CD40L and loaded with pp65 peptide $(10 \mu \mathrm{g} / \mathrm{ml})$ (NLVPMVATV) were used as stimulator cells. The CD14 ${ }^{+}$cells depleted peripheral blood lymphocytes (PBLs) $\left(1 \times 10^{5}\right.$ cells/ well) were mixed with activated $B$ cells $\left(1 \times 10^{4}\right.$ cells/well) After cells had been incubated in $200 \mu \mathrm{l}$ complete medium in a U-bottomed 96-well plate (Falcon, Bedford, MA) for $4 \mathrm{~h}$, all the aliquots were transferred into an IFN-r coated ELISPOT plate and incubated for an additional $20 \mathrm{~h}$. To visualize spots, streptavidin-HRP, and substrate were used. Spots were counted after computerized visualization using a reader (AID, Jessup, MD).

\section{Statistical analysis}

Data are expressed as means \pm SD. Differences were considered statistically significant for $P$ values using a Student's $t$-test compared to other groups.

\section{Results}

\section{Stable S2 transfectant expressing CD40L}

S2 cells was co-transfected with the CD40L expression plasmid containing constitutive Ac5 promoter and selection vector plasmid encoding hygromycin resistant gene (Figure 1). The transfectants were selected with hygromycin-B and tested for its expression using PE-conjugated CD40L ( $>$ $90 \%$ ) by flow cytometry. Its expression was stable for a year and often analyzed by flow cytometry.

To verify whether CD40L expression can be maintained at which $\mathrm{B}$ cells are cultured, $37^{\circ} \mathrm{C}$, S2CD40L transfectants were suspended in B cell media, IMDM (10\% FBS) and incubated at $37^{\circ} \mathrm{C}$. A fraction of cultured S2-CD40L cells was daily analyzed for its CD40L expression by flow cytometry and Figure $2 \mathrm{~A}$ shows the expression maintained up to at least 3 days even at $37^{\circ} \mathrm{C}$.

When S2-CD40L transfectants were cultured at $37^{\circ} \mathrm{C}$, we hourly observed membrane instability through microscopic analysis and found out the degree of instability increased as the culture period extends (data not shown). Therefore we tested to define whether incubation at different temperature leads S2-CD40L to either necrosis or apoptosis using apoptosis kit by staining with 7AAD for necrosis and annexinV for apoptosis. As the incubation time increases, the number of cells stained for annexinV increased from day $0,1,2$ to $3 ; 2 \%, 32 \%$, $48 \%$, and $68 \%$ respectively (Figure $2 \mathrm{~B}$ ). The first day

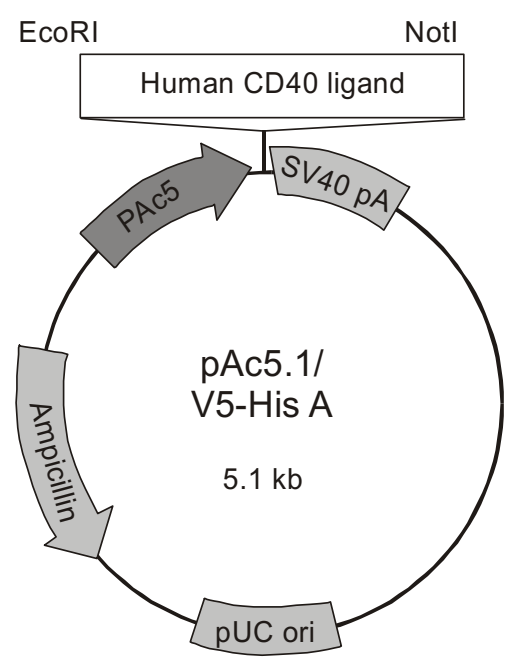

Figure 1. Schemic representations to generate CD40L gene construction. The cDNA encoding human CD40L (hCD40L) is derived from the activated $\mathrm{CD}^{+} \mathrm{T}$ cells by extracting RNA using with EcoRI and Notl restriction site hanging at the $5^{\prime}$ and $3^{\prime}$ terminal respectively. The amplified hCD40L is then inserted into the $\mathrm{S} 2$ constitutive expression vector pAc5.1-V5/HisA. 
of culture at $37^{\circ} \mathrm{C}$ leads the number of population stained for apoptosis from $2 \%$ to $30 \%$ and two more days of culture increased more than two folds.

\section{B cell activation by coculturing with S2-CD40L}

To investigate whether S2-CD40L/B ratio is critical in activating $B$ cells, we incubated different numbers of
S2-CD40L with a fixed number of $B$ cells at the ratios from 1:16 to $1: 1$. Although the activated cells seemed "clumped" at every ratio, Figure $3 \mathrm{~A}$ shows the maximal increase of total $B$ cells at the ratio of $B$ cells to S2-CD40L, 2:1. Although B cells were tested at the ratio of $1: 1$, the increase of $B$ cells was similar to the ratio of $2: 1$. Figure $3 \mathrm{~B}$ showed that S2-CD40L stimulated $B$ cells more efficiently than anti-CD40 mAb
A
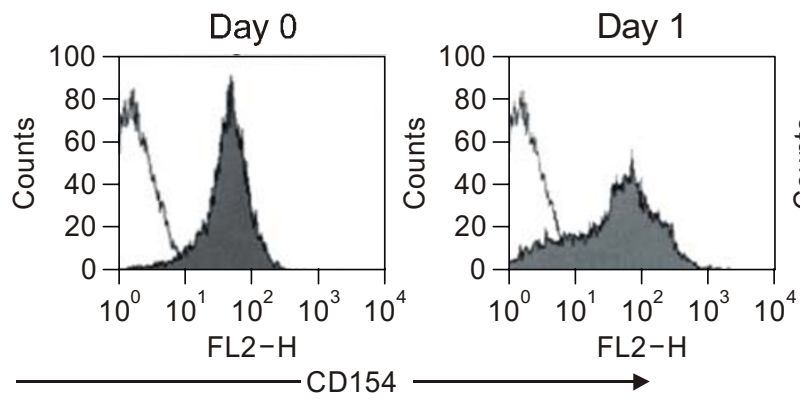

B

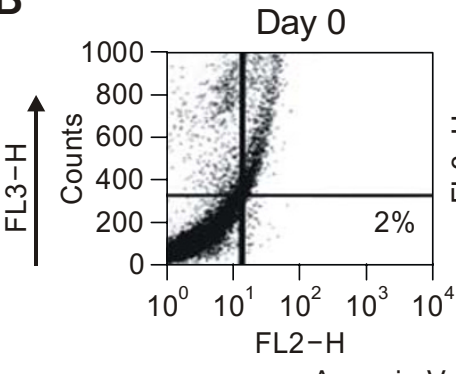

Day 1

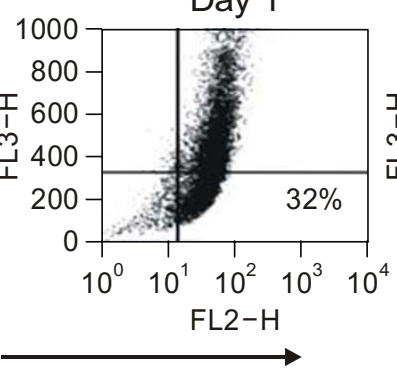

Day 2

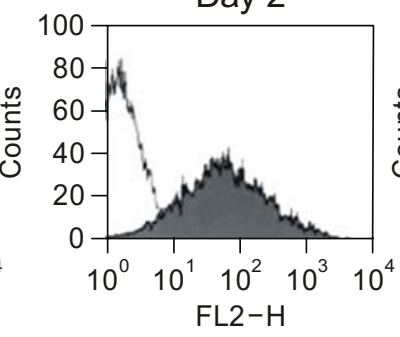

Day 2

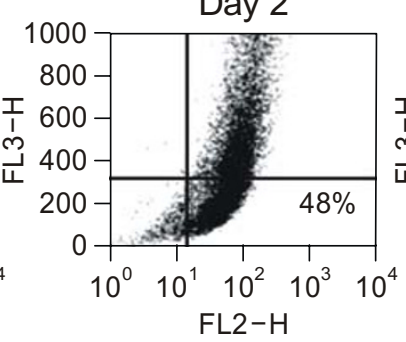

Day 3

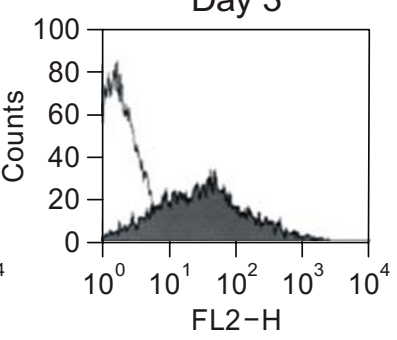

Figure 2. Expression of $\mathrm{CD} 40 \mathrm{~L}$ on $\mathrm{S} 2$ cells and apoptosis at $37^{\circ} \mathrm{C}$. (A) $\mathrm{CD} 40 \mathrm{~L}$ expressing stable transfectant of $\mathrm{S} 2$ is sorted by drug selection, hygromycin B. The surface markers on S2-CD40L were tested with PE-conjugated human CD154 (CD40L). The stable surface expression of CD40L was shown on day $0,1,2$ and 3 when cultured at $37^{\circ} \mathrm{C}$. (B) The apoptosis and necrosis of S2-CD40L at $37^{\circ} \mathrm{C}$ were tested with PE-conjugated annexinV and $7 A A D$ on day $0,1,2$ and 3 .

A

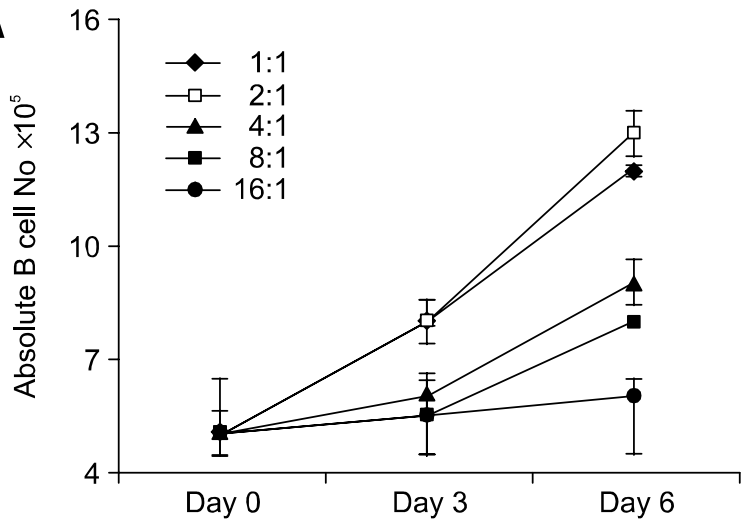

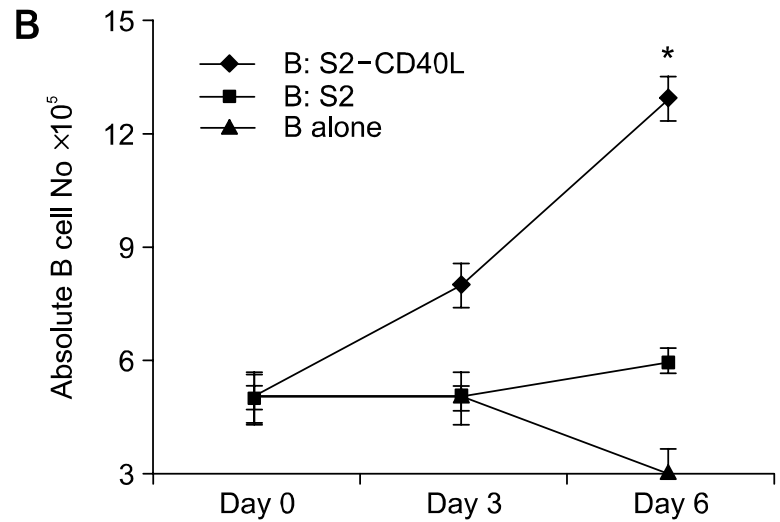

Figure 3. B cell proliferation using S2-CD40L or anti-CD40 mAb. (A) B cells at $5 \times 10^{5} /$ well were placed in a 12-well plate. Various numbers of S2-CD40L were then added to each well. B cells in the culture were determined by morphology and phenotype. (B) B cells at $2 \times 10^{5} /$ well plated in a 12-well plate were stimulated with control S2 cells, anti-CD40 mAb $(10 \mu \mathrm{g} / \mathrm{ml})$ or S2 cells expressing CD40L. Data are means \pm SD of triplicate independent determinations. ${ }^{*}, P<0.01$ for increase of $B$ cell number between B cells stimulated with S2-CD40L and B cells stimulated with anti-CD40 mAb. 
$\mathrm{B}+\mathrm{S} 2-\mathrm{CD} 40 \mathrm{~L}$
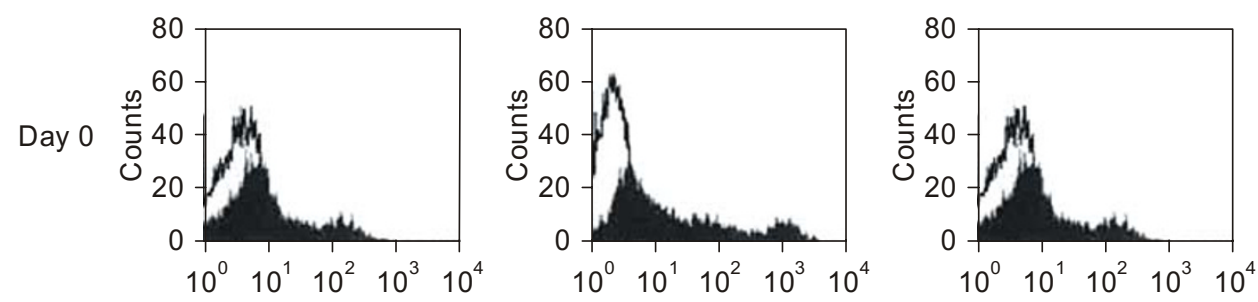

$\mathrm{B}+\mathrm{S} 2$
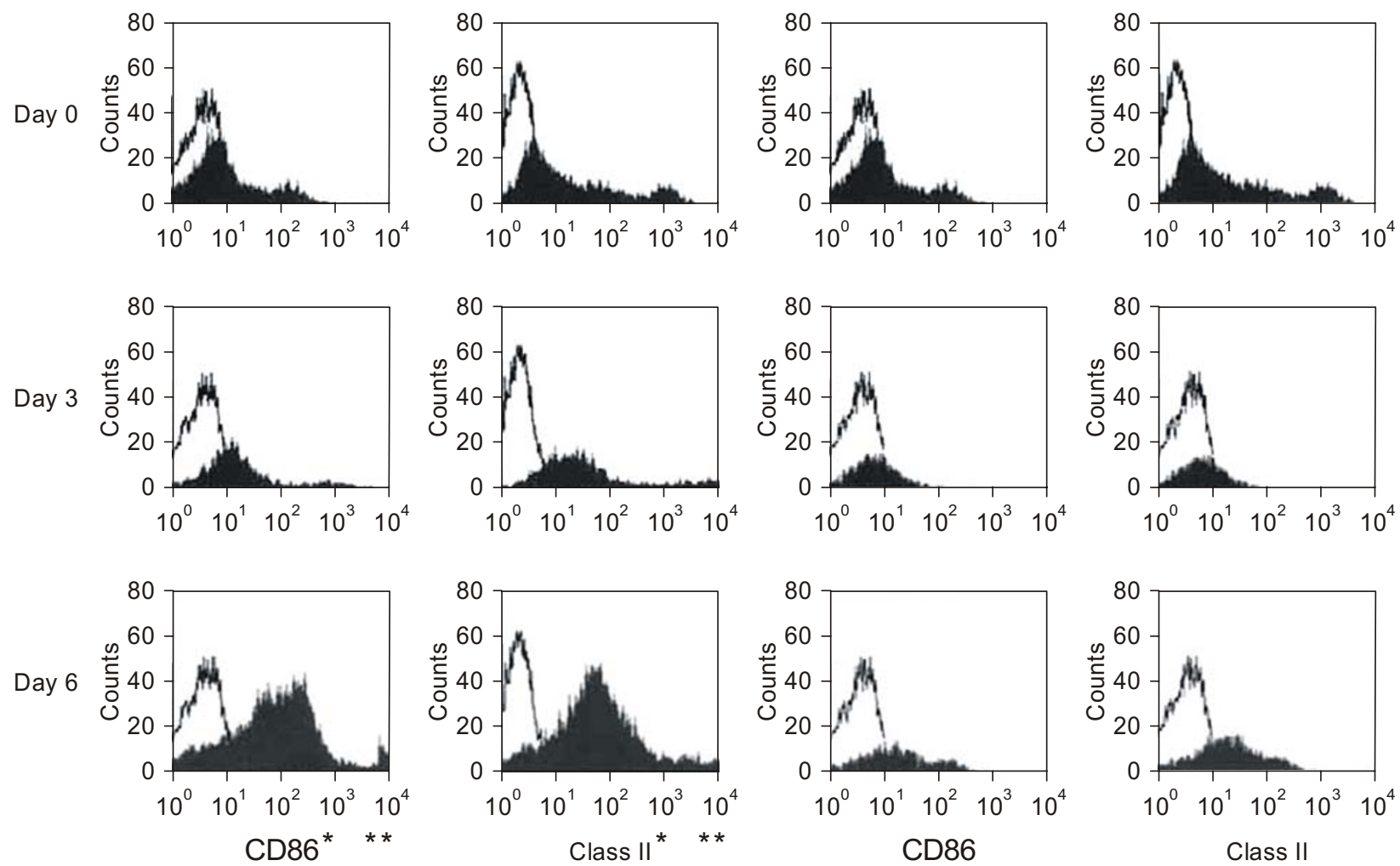

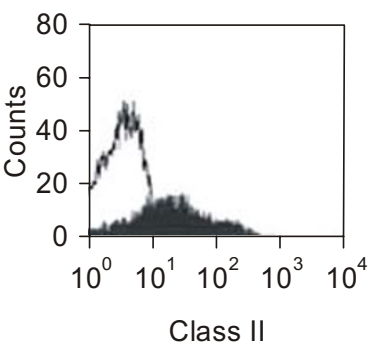

Figure 4. Induction of CD86 and HLA Class II molecules in B cells stimulated with S2-CD40L. B cells at $2 \times 10^{5} /$ well were placed in a 12-well plate. The ratio of $B$ cells to $\mathrm{S2}-\mathrm{CD} 40 \mathrm{~L}$ is fixed at 2:1 and after coincubation for 3 days and 6 days, the costimulatory molecule CD86 and MHC molecule are analyzed on B cells, the shaded area. Empty area indicates fluorescence of isotype matched conjugated antibodies. Data are representative of at least five separate experiments in three different individuals. ${ }^{*}, P<0.01$ for change in phenotypes of B cells stimulated with S2-CD40L at day 3 or 6 ; ${ }^{* *}, P>$ 0.05 for change in phenotypes of B cells stimulated with anti-CD40 mAb at day 6 .

in B cell proliferation for 6 days $(P<0.01)$. B cells incubated alone or cultured with S2 cells (S2-B) did not increase in cell number and eventually died after all.

To examine the phenotypic change on $B$ cells, a fraction of $B$ cells on day 0,3 and 6 was tested for the expression of costimulatory CD86 and MHC Class II molecules. These cells were highly activated as shown by the increase of activation marker in Figure 4. The expression of CD86 and MHC Class II by day 6 was highly increased compared to that by day 0 and $3(P<0.01)$. On day 3 , the expression of CD86 and Class II did not increase significantly and remained similar levels as in day 0 . However after the second stimulation of B cells with S2-CD40L on day 3 and further incubation, the expression of activation marker increased significantly $(P<0.01)$. In comparison, B cells stimulated with control S2 cells did not show significant phenotypic changes $(P$ $>0.05$ ). We also examined the expression of activated $B$ cells cultured more than 6 days and expression of these molecules along with $B$ cells lineage marker remained stable thereafter (data not shown).

\section{Efficient stimulation of $T$ cells by $B$ cells activated with S2-CD40L}

To assess APC capacity of activated B cells cultured with S2-CD40L or anti-CD40 mAb, B cells were harvested at day 6 and used as stimulators for $\mathrm{CD}^{+}$ T cells. In MLR of Figure 5A, B cells activated with S2-CD40L could significantly increase $T$ cell proliferation $(P<0.01)$ compared to those of $\mathrm{B}$ cells incubated alone or B cells cultured with S2 cells (S2-B). Furthermore, B cells activated with antiCD40 mAb were not as efficient as B cells activated with S2-CD40L $(P=0.01)$. To also evaluate the capacity of antigen presenting capacity of $B$ cells activated with S2-CD40L, we pulsed the B cells with the immunogenic HLA-A*0201 binding peptide from pp65, HCMV associated antigen, and subsequently stimulated PBLs. As shown in ELISPOT assay of Figure 5B, CD40 activated $B$ cells pulsed with peptide induced IFN- $\gamma$ secreting $T$ cells $(50 \pm 1.04)$ in $10^{5}$ PBLs $(P<0.01)$. In contrast, no or a few IFN- $\gamma$ spots were formed against PBLs only, PBLs with unpulsed B cells or PBLs with S2-B cells, 
A

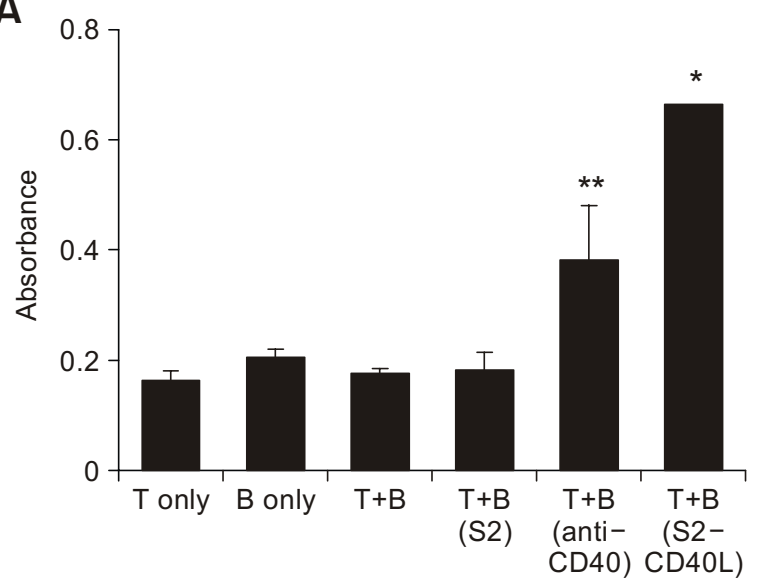

B

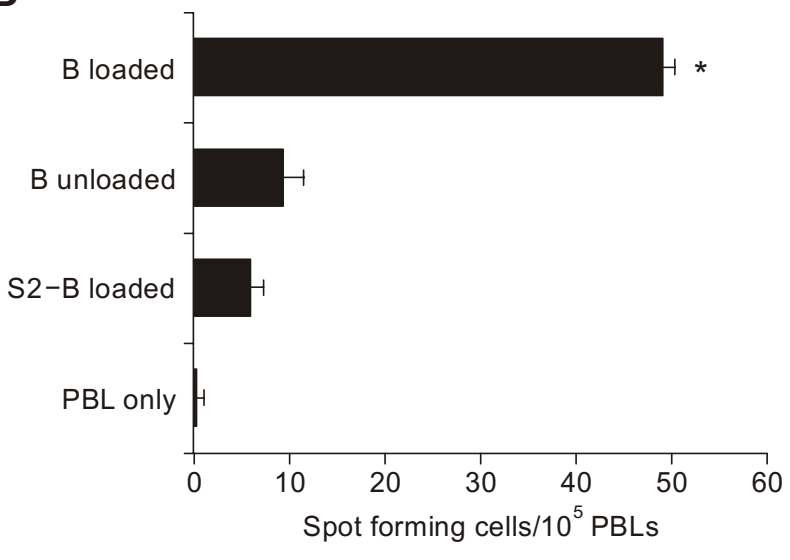

Figure 5. MLR or IFN- $\gamma$ ELISPOT assay using HCMV pp65 peptide pulsed CD40 activated B cells. (A) Induction of T cell proliferation was performed with unstimulated B cells, B cells stimulated with S2 cells, stimulated with anti-CD40 or B cells stimulated with S2-CD40L cells precultured for 6 days. Purified $C D 3^{+} C D 4^{+} T$ cells were cocultured with $B$ cells or activated B cells in a final volume of $100 \mu$ l. MLRs were cultured for 6 days and proliferating viable cells were analyzed by XTT assay. One of three experiments is shown. Data are means $\pm S D$ of triplicate independent determinations. ${ }^{*}, P<$ 0.01 for T cells proliferation by activated B cells with S2 cells (S2-B) compared to B cells with S2-CD40L; ${ }^{* *}, P<0.01$ for T cells proliferation by activated $B$ cells with control $S 2$ cells compared to $B$ cells with anti-CD40 mAb. (B) HLA-A*0224 ${ }^{+} P B L$ from two normal donors were stimulated with autologous CD40 activated B cells and subsequently analyzed for their immune response by ELISPOT. Stimulator cells were autologous CD40-activated B cells from two donors pulsed with the specific CMV antigen pp65 peptide. ELISPOT reader measured spots formed by IFN- $\gamma$ secreting T cells. Data are mean \pm SD of triplicate independent determinations. ${ }^{*}, P<0.01$ for spot forming cells by antigen loaded activated $B$ cells with S2-CD40L compared to B cells with control S2 cells.

respectively. These data indicate that stimulation with peptide pulsed CD40 activated B cells induced peptide-specific IFN- $\gamma$ secreting T cells in vitro.

\section{Discussion}

Previous studies on B cell activation have been done with various types of CD40L. Mainly the two forms including soluble $\mathrm{CD} 40 \mathrm{~L}$ and membrane bound CD40L could be used. Michael et al., (2002) showed that GMP-grade soluble trimeric CD40L can be used to activate $B$ cells and demonstrated its capacity to generate antigen specific T cells in vitro. Although maintaining constitutive expression of CD40L of membrane-bound form is laborious and operating with soluble CD40L is convenient, soluble CD40L is known to have a lower stimulating potential than membrane-bound form. Among the membrane-bound form of CD40L, NIH3T3 expressing CD40L, was mostly used to activate B cells. Recently 293T cells were also manipulated to express CD40L and demonstrated the complete activation and significant proliferation of $B$ cells (Ivanov et al., 2005). However using mammalian expression to activate B cells provides concerns such as allogenic response for 293T and xenogenic response for NIH3T3 cells. To avoid those issues, Wendy et al., (1995) established Spodopzeru frugiperda cell line, SF9, to express CD40L and stimulated B cells to activate. However CD40L on SF9 cells is expressed in a baculovirus system, thus safety concerns for viral product from infected SF9 cells cannot be ignored. In contrast to previous studies on activating B cells (Joachim et al., 1995; G.A. et al., 2005), we used insect embryo cell line, S2 that has been used as artificial APC (AAPC). Mammalian cells used as AAPC provided concerns for nonspecific stimulation of $\mathrm{CD}^{+}$and reactivity of natural killer cells (Janetzki et al., 2000). However, the fact that insect cells do not process or present antigens through MHC class pathway due to the lack of endogenous machinery lowered reactivity against insect cells by effector cells. In addition, mammalian cell lines used as AAPC need to be irradiated in order to stimulate $\mathrm{T}$ cells, however S2 cells are conveniently self-eliminated at $37^{\circ} \mathrm{C}$, thus irradiation step is unnecessary when cultured, in this case for activating $B$ cells.

Current study has utilized CD40-CD40L interaction of $B$ cell to activate and mature to become a potent APC. By genetical manipulation of S2 cells, we established a cell line constitutively expressing CD40L, a molecule mostly used to activate B cells. From the incubation of S2-CD40L and B cells only for 6 days, we observed proliferation, changes in morphology and maturation marker, CD86 and MHC Class II on B cells. MLR using B cells activated with S2-CD40L as APC showed that activated B cells could induce $T$ cell proliferations and demonstrated 
that the capacity of $S 2-C D 40 L$ in B cell activation was superior to that with anti-CD40 mAb as soluble form. In addition, we also pulsed B cells with CMV antigen pp65 peptide and examined IFN-r secretion by PBLs as analyzed by ELISPOT assay. In contrast to monocyte-derived dendritic cells, B cells proliferated as long as stimulator cells were present. A fraction of the activated $B$ cells can be used to stimulate $T$ cells and the rest can be recultured until later use while maintaining APC capacity. This advantage eliminates subsequent blood draw from either patients or donors every time to stimulate $\mathrm{T}$ cells. Although the ability of CD40-activated B cells needs to be examined for its capacity of migration and induction of priming $T$ cells in vivo, these results underscore that CD40 activated B cells can act as alternative APC for the ex vivo induction of $\mathrm{T}$ cell immune responses, as was shown previously for mRNA-loaded DC (Van et al., 2001; Posaerts et al., 2003).

In addition to CD40 activated B cells, B cells immortalized using EBV lymphoblastic cell line (EBV$\mathrm{LCL})$ efficiently expanded Ag-specific T cells $\left(\mathrm{CD} 4^{+}\right.$ and $\mathrm{CD}^{+}$) and demonstrated its capacity as APC (Sun et al., 1987; Okamura et al., 2003). Although generation of EBV-LCL is simple and can be expanded while maintaining its APC function, the safety concern of using live virus to generate LCL still remains and it requires about 4-6 weeks to be established. Currently, our lab seeks to generate "APC cocktail" including LCL, DC and CD40 activated B cells to efficiently stimulate $T$ cells in vitro. The use of APC combination including LCL, DC and CD40 activated $B$ cells may overcome the limitation of use of single APC. Each APC would function its potent role in different mechanism and the use of APC cocktail will generate more efficient and natural form of cytotoxic T lymphocytes. In this study, we suggest that activated $B$ cells can be easily and conveniently generated using insect cell line, S2-CD40L and the results of this study may impact on the development of $B$ cell-based anticancer immunotherapy.

\section{Acknolwdgement}

This study was supported by a grant of the Korea Health 21 R\&D Project, Ministry of Health and Welfare, Republic of Korea (0405-DB01-0104-0006).

\section{References}

Banchereau J, Palucka AK, Dhodapkar M, Burkeholder S, Taquet N, Rolland A, Taquet S, Coquery S, Wittkowski KM, Bhardwaj N, Pineiro L, Steinman R, Fay J. Immune and clinical responses in patients with metastatic melanoma to CD34(+) progenitor-derived dendritic cell vaccine. Cancer Res 2001;61:6451-8

Savoldo B, Cubbage ML, Durett AG, Goss J, Huls MH, Liu Z,
Teresita L, Gee AP, Ling PD, Brenner MK, Heslop HE, Rooney CM. Generation of EBV-specific CD4+ cytotoxic T cells from virus naive individuals. J Immunol 2002;168:909-18

Bender A, Sapp M, Schuler G, Steinman RM, Bhardwaj N Improved methods for the generation of dendritic cells from nonproliferating progenitors in human blood. J Immunol Meth 1996;196:121-35

Celluzzi CM, Mayordomo JI, Storkus WJ, Lotze MT, Falo LD Jr. Peptide-pulsed dendritic cells induce antigen-specific cytotoxic T lymphocyte-mediated protective tumor immunity. J Exp Med 1996;183:283-7

Constant S, Schweitzer N, West J, Ranney P, Bottomly K. B lymphocytes can be competent antigen-presenting cells for priming CD4+ T cells to protein antigens in vivo. J Immunol 1995; 155:3734-41

Kondo E, Topp MS, Kiem HP, Obata Y, Morishima Y, Kuzushima K, Tanimoto M, Harada M, Takahashi T, Akatsuka Y. Efficient generation of antigen-specific cytotoxic $T$ cells using retrovirally transduced CD40-activated B cells. The Journal of Immunology 2002;169:2164-71

Girolomoni G, Ricciardi-Castagnoli P. Dendritic cells hold promise for immunotherapy. Immunol Today 1997;18:102-4

Gollob KJ, Nagelkerken L, Coffman RL. Endogenous retroviral superantigen presentation by $\mathrm{B}$ cells induces the development of type $1 \mathrm{CD} 4+\mathrm{T}$ helper lymphocytes. Eur J Immunol 1993;23:2565-71

Heiser A, Coleman D, Dannull J, Yancey D, Maurice MA, Lallas CD, Dahm P, Niedzwiecki D, Gilboa E, Vieweg J. Autologous dendritic cells transfected with prostate-specific antigen RNA stimulate CTL responses against metastatic prostate tumors. J Clin Invest 2002;109:409-17

Hsu FJ, Benike C, Fagnoni F, Liles TM, Czerwinski D, Taidi $B$, Engleman EG, Levy R. Vaccination of patients with B-cell lymphoma using autologous antigen-pulsed dendritic cells. Nat Med 1996;2:52-8

Inaba K, Metlay JP, Crowley MT, Steinman RM. Dendritic cells as antigen presenting cells in vivo. Int Rev Immunol 1990;6:197-206

Inaba K, Metlay JP, Crowley MT, Steinman RM. Dendritic cells pulsed with protein antigens in vitro can prime antigen-specific, MHC-restricted T cells in situ. J Exp Med 1990;I172: 631-40

Ivanov R, Aarts T, Hagenbeek A, Hol S, Ebeling S. B-cell expansion in the presence of the novel 293-CD40L-sCD40L cell line allows the generation of large numbers of efficient xenoantigen-free APC. Cytotherapy 2005;7:62-73

Janetzki S, Song P, Gupta V, Lewis JJ, Houghton AN. Insect cells as HLA restricted antigen-presenting cells for the IFNgamma elispot assay. J Immunol Methods 2000;234:1-12

Kim A, Noh YW, Kim KD, Jang YS, Choe YK, Lim JS. Activated natural killer cell-mediated immunity is required for the inhibition of tumor metastasis by dendritic cell vaccination. Exp Mol Med 2004;36:428-43

Kondo E, Topp MS, Kiem HP, Obata Y, Morishima Y, Kuzushima K, Tanimoto M, Harada M, Takahashi T, Akatsuka Y. Efficient generation of antigen-specific cytotoxic $T$ cells using retrovirally transduced CD40-activated B cells. J Immunol 2002;169:2164-71 
Kugler A, Stuhler G, Walden P, Zoller G, Zobywalski A, Brossart P, Trefzer U, Ullrich S, Muller CA, Becker V, Gross AJ, Hemmerlein B, Kanz L, Muller GA, Ringert RH. Regression of human metastatic renal cell carcinoma after vaccination with tumor cell-dendritic cell hybrids. Nat Med 2000;6:332-6.

Lee EJ, Kim J, Lee SA, Kim EJ, Chun YC, Ryu MH, Yook JI. Characterization of newly established oral cancer cell lines dervied from six squamous cell carcinoma and two mucoepidermoid carcinoma cells. Exp Mol Med 2005;37:379-90

Liu KJ, Parikh VS, Tucker PW, Kim BS. Surface immunoglobulins mediate efficient transport of antigen to lysosomal compartments resulting in enhanced specific antigen presentation by B cells. Eur J Immunol 1994;24: 2755-60

Liu YJ, Barthelemy C, de Boutelier O, Arpin C, Durand I, Banchereau J. Memory B cells from human tonsils colonize mucosal epithelium and directly present antigen to $T$ cells by rapid up-regulation of B7-1 and B7-2. Immunity 1995;2: 239-48

Livingston PG, Kurane I, Ennis FA. Use of Epstein-Barr virus-transformed, autologous B-lymphoblastoid cells as antigen-presenting cells for establishment and maintenance of dengue virus-specific, human cytotoxic $\mathrm{T}$ lymphocyte clones. J Virol Methods 1997;67:77

Maier T, Tun-Kyi A, Tassis A, et al. Vaccination of cutaneous $\mathrm{T}$ cell lymphoma patients using intranodal injection of autologous tumor lysate pulsed dendritic cells. Blood 2003;102:2338-44

Metlay JP, Pure E, Steinman RM. Control of the immune response at the level of antigen-presenting cells: a comparison of the function of dendritic cells and B lymphocytes. Adv Immunol 1989;47:45-116

Mitchell RN, Barnes KA, Grupp SA, Sanchez M, Misulovin Z, Nussenzweig MC, Abbass AK. Intracellular targeting of antigens internalized by membrane immunoglobulin in B lymphocytes. J Exp Med 1995;181:1705-14

Okamura T, Uluhan S, Rooney CM. Antigen-presenting capabilities of retrovirus-transduced T cell blasts. Blood 2003; 102:285a

Paglia P, Chiodoni C, Rodolfo M, Colombo MP. Murine dendritic cells loaded in vitro with soluble protein prime cytotoxic T lymphocytes against tumor antigen in vivo. J Exp Med 1996;183:317-22

Ponsaerts P, Van Tendeloo V, Berneman ZN. Cancer immunotherapy using RNA-loaded dendritic cells. Clin Exp Immunol 2003;134:378-84

Rini BI. Technology evaluation. APC-8015, Dendreon. Curr Opin Mol Ther 2002;4:76-9

Rock KL, Rothstein L, Gamble S, Fleischacker C. Characterization of antigen-presenting cells that present exogenous antigens in association with class I MHC molecules. J Immunol 1993;150:438-46

Romani N, Koide S, Crowley M, Witmer-Pack M, Livingstone AM, Fathman CG, Inaba K, Steinman RM. Presentation of exogenous protein antigens by dendritic cells to $T$ cell clones. Intact protein is presented best by immature, epidermal Langerhans cells. J Exp Med 1989;169:1169-78

Sallusto F, Lanzavecchia A. Efficient presentation of soluble antigen by cultured human dendritic cells is maintained by granulocyte/macrophage colony-stimulating factor plus interleukin 4 and downregulated by tumor necrosis factor alpha. $\mathrm{J}$ Exp Med 1994;179:1109-18

Schultze JL, Cardoso AA, Freeman GJ, Seamon MJ, Daley J, Pinkus GS, Gribben JG, Nadler LM. Follicular lymphomas can be induced to present alloantigen efficiently: a conceptual model to improve their tumor immunogenicity. Proc Natl Acad Sci USA 1995;92:8200-4

Schultze JL, Michalak S, Seamon MJ, Dranoff G, Jung K, Daley J, Delgado JC, Gribben JG, Nadler LM. CD40activated human $B$ cells: an alternative source of highly efficient antigen presenting cells to generate autologous antigen-specific $\mathrm{T}$ cells for adoptive immunotherapy. J Clin Invest 1997 1;100:2757-65

Steinman RM, Witmer-Pack MD, Inaba K. Dendritic cells: antigen presentation, accessory function and clinical relevance. Adv Exp Med Biol 1993;329:1-9

Liu YN, Fuad S, Gehrz RC. Epstein-Barr virus-transformed lymphoblastoid cell lines as antigen-presenting cells and "augmenting" cells for human CMV-specific Th clones. Cell Immunol 1987;108:64-75

Thurner B, Haendle I, Roder C, Dieckmann D, Keikavoussi $P$, Jonuleit $H$, Bender $A$, Maczek $C$, Schreiner $D$, von den Driesch P, Brocker EB, Steinman RM, Enk A, Kampgen E, Schuler G. Vaccination with Mage-3A1 peptide-pulsed mature, monocyte-derived dendritic cells expands specific cytotoxic $T$ cells and induces regression of some metastases in advanced stage IV melanoma. J Exp Med 1999;11:1669-78

Topalian SL, Rivoltini L, Mancini M, Ng J, Hartzman RJ, Rosenberg SA. Melanoma-specific CD4+ T lymphocytes recognize human melanoma antigens processed and presented by Epstein-Barr virus-transformed B cells. Int J Cancer 1994;58:69-79

Van den Bosch GA, Ponsaerts P, Nijs G, Lenjou M, Vanham G, Van Bockstaele DR, Berneman ZN, Van Tendeloo VF. Ex vivo induction of viral antigen-specific $\mathrm{CD} 8^{+} \mathrm{T}$ cell responses using mRNA-electroporated CD40-activated B cells. Clin Exp Immunol 2005;139:458-67

Van Tendeloo VF, Ponsaerts P, Lardon F, Nijs G, Lenjou M, Van Broeckhoven C, Van Bockstaele DR, Berneman ZN. Highly efficient gene delivery by mRNA electroporation in human hematopoietic cells: superiority to lipofection and passive pulsing of mRNA and to electroporation of plasmid cDNA for tumour antigen loading of dendritic cells. Blood 2001;98:49-56

Vidard L, Kovacsovics-Bankowski M, Kraeft SK, Chen LB, Benacerraf B, Rock KL. Analysis of MHC class II presentation of particulate antigens of $B$ lymphocytes. J Immunol 1996;156:2809-18

von Bergwelt-Baildon MS, Robert $\mathrm{H}$, et al. Human primary and memory cytotoxic $\mathrm{T}$ lymphocyte responses are efficiently induced by means of CD40-activated B cells as antigen-presenting cells: potential for clinical application. Blood 2002; $99: 3319-25$

Warren WD, Berton MT. Related Articles, Links Induction of germ-line gamma 1 and epsilon $\mathrm{lg}$ gene expression in murine B cells. IL-4 and the CD40 ligand-CD40 interaction provide distinct but synergistic signals. J Immunol 1995;155: 5637-46 